\title{
Correction: S100A6 is a critical regulator of hematopoietic stem cells
}

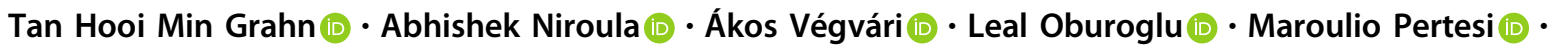 \\ Sarah Warsi (1) - Fatemeh Safi (10) Natsumi Miharada (1) - Sandra Capellera-Garcia (1) - Kavitha Siva - Yang Liu • \\ Emma Rörby · Björn Nilsson • Roman A. Zubarev · Stefan Karlsson (1)
}

Published online: 14 July 2020

(c) The Author(s) 2020. This article is published with open access

\section{Correction to: Leukemia \\ https://doi.org/10.1038/s41375-020-0901-2}

This article was originally published without the accompanying Supplementary figures. This file is now available in the HTML version of the article; the PDF was correct from the time of publication. Furthermore, the author Sandra C. Garcia is now displayed in both PDF and HTML as Sandra Capellera-Garcia as requested by the author.

\begin{abstract}
Open Access This article is licensed under a Creative Commons Attribution 4.0 International License, which permits use, sharing, adaptation, distribution and reproduction in any medium or format, as long as you give appropriate credit to the original author(s) and the source, provide a link to the Creative Commons license, and indicate if changes were made. The images or other third party material in this article are included in the article's Creative Commons license, unless indicated otherwise in a credit line to the material. If material is not included in the article's Creative Commons license and your intended use is not permitted by statutory regulation or exceeds the permitted use, you will need to obtain permission directly from the copyright holder. To view a copy of this license, visit http://creativecommons. org/licenses/by/4.0/.
\end{abstract}

